\title{
Immunohistochemical demonstration of different latent membrane protein-1 epitopes of Epstein-Barr virus in lymphoproliferative diseases
}

\author{
N M Jiwa, J J Oudejans, D F Dukers, W Vos, A Horstman, P van der Valk, \\ J M Middledorp, J M M Walboomers, C J L M Meijer
}

\begin{abstract}
Aim-To compare the immunoreactivity of monoclonal antibodies S12 and CS1-4, which recognise different epitopes of the Epstein-Barr virus (EBV) latent membrane protein-1 (LMP-1), in EBV associated benign and malignant lymphoproliferative disorders and control tissues processed using different methods.

Results-Both monoclonal antibodies gave comparable results on frozen tissue sections and formalin fixed, paraffin wax embedded samples from cases with Hodgkin's disease and infectious mononucleosis. In all cases $\mathrm{S} 12$ stained more cells than CS1-4. For EBV associated B and $T$ non-Hodgkin's lymphomas, frozen tissue sections yielded better LMP-1 staining results than formalin fixed material. Again, in all these cases $\mathrm{S} 12$ stained more cells and gave stronger results than CS1-4. For EBV negative tissues, both monoclonal antibodies showed cross-reactivity with melanocytic-like cells in the basal cell layer of the skin, synaptophysin-like staining in layers three and four of the cortex of the brain, and myelin-like staining in peripheral nerves and peripheral ganglion cells. Staining with $\mathrm{S} 12$ was always much stronger. Moreover, in contrast to $\mathrm{CS1}-4, \mathrm{~S} 12$ stained pancreatic islands in formalin fixed material but not in frozen tissue sections and sporadically stained solitary epithelial cells in the large bowel especially in formalin fixed tissue sections. CS1-4 also cross-reacted with myoepithelial cells around hair follicles and other adnexa of the skin.

Conclusion-The results indicate that for optimal detection of LMP-1, S12 yields better results than $\mathrm{CS} 1-4$ and that tissue processing is very important especially when $B$ and $T$ non-Hodgkin's lymphomas are examined.
\end{abstract}

(f Clin Pathol 1995;48:438-442)

Keywords: Epstein-Barr virus, latent membrane protein-1, monoclonal antibody, Hodgkin's disease.

Epstein-Barr virus (EBV) is associated with different lymphoproliferative disorders, both benign and malignant. ${ }^{1-6}$ Although the precise role of EBV in cellular transformation is unknown, different viral gene products seem to be involved, in particular the Epstein-Barr nuclear antigens (EBNAs) and the latent membrane protein-1 (LMP-1). ${ }^{7}$ At present, only a few EBV products can be demonstrated immunohistochemically, LMP-1 being one of these. LMP-1 has been detected in EBV associated Hodgkin's disease, $B$ and T cell nonHodgkin's lymphoma and in infectious mononucleosis. ${ }^{458}$ This protein has transforming potential in vitro ${ }^{9-11}$ and may be involved in the pathogenesis of EBV linked neoplastic diseases.

LMP-1 expression has been found in typical Reed-Sternberg (RS) cells and their mononuclear variants (Hodgkin; $\mathrm{H}$ cells). The frequency of LMP-1 positive $\mathrm{H}-\mathrm{RS}$ cells may vary considerably, from 10 to $80 \% .{ }^{12}{ }^{13}$ To date, it is not known why not all cells infected with EBV in a clonal population express LMP-1. In EBV positive Hodgkin's disease technical reasons, such as the type of fixation and fixation time etc., might explain why not all H-RS cells are stained. In non-Hodgkin's lymphoma arising in patients without an overt immunodeficiency only a few LMP-1 positive neoplastic cells could be detected, even when frozen tissue sections were examined. ${ }^{58}$ Thus, before a correct interpretation of immunohistochemical findings of LMP-1 expression can be made, one must be certain that the immunohistochemical detection method used is reliable and as sensitive as possible.

LMP-1 expression in lymphomas has usually been investigated using one set of four different monoclonal antibodies: CS1-4. ${ }^{14}$ In 1985 another monoclonal antibody against LMP-1, called S12 (OT17), was described. ${ }^{15} \mathrm{Re}-$ markably, the use of this monoclonal antibody has been only described for the detection of LMP-1 in EBV positive Hodgkin's disease thus far. ${ }^{16}$ Both S12 and CS1-4 are directed against the same $\beta$-galactosidase fusion protein. ${ }^{17}$ At least three different epitopes with marked differences in reactivity on western blots and immunocytochemistry are detected by CS1-4. On the other hand, S12 has a slightly different reaction pattern on western blots and on cell lines, suggesting that the epitope detected is not exactly the same. ${ }^{1415}$

In the present study we compared the results of immunohistochemical staining with $\mathrm{S} 12$ and CS1-4 for the detection of LMP-1 positive cells in infectious mononucleosis, Hodgkin's disease and B and T non-Hodgkin's lymphoma 
in both immunocompetent and immunocompromised patients. Special attention was paid to tissue processing (formalin fixed, paraffin wax embedded versus frozen tissue sections), and cross-reactivity of the monoclonal antibody on normal tissue, EBV negative tissue and EBV negative neoplastic samples.

\section{Methods}

The only tissues used in this study were those which harboured EBV DNA sequences as detected by the polymerase chain reaction (PCR) using primers selected from the large internal repeat of the B95.8 strain and which showed diffuse staining on RNA in situ hybridisation using EBER-1 and -2 probes. The EBV DNA PCR and the RNA in situ hybridisation procedures have been described in detail elsewhere. ${ }^{4818}$

Five different groups of EBV associated lymphoproliferative disorders were included in this study: (1) tonsil tissue samples from four patients with serological and clinical evidence of infectious mononucleosis; (2) lymph nodes from five patients with Hodgkin's disease; (3) lymph nodes, large intestine, pancreas, liver, adrenal gland, and kidney involved in B immunoblastic lymphoma from four bone marrow transplant recipients; (4) three lymph nodes involved in B cell non-Hodgkin's lymphoma and three lymph nodes involved in $\mathrm{T}$ cell nonHodgkin's lymphoma from six immunocompetent patients. Three non-malignant lymph nodes which reacted positively in the EBV DNA PCR and in which sporadic EBER-1 and -2 positive cells were detected were also included in this study.

The following non-malignant tissue samples were used: tonsil, hyperplastic lymph nodes, spleen, thymus, appendix, small and large intestine, stomach, liver, pancreas, lung, urinary bladder, kidney, prostate, thyroid, adrenal gland, pituitary gland, skin, testis, ovary and brain, and peripheral nerves.

On the basis of the reactivity with non-malignant tissue, histiocytosis $\mathrm{X}$, insulinoma, and cutaneous melanoma tissue samples were also investigated.

\section{IMMUNOHISTOCHEMISTRY}

S12 (OT17) lgG2a monoclonal antibody was obtained from Organon Teknika (Boxtel, The Netherlands). S12 was produced in a serum free hollow fibre cell culture system and subsequently purified over a protein A column. For immunohistochemistry, a final concentration of $0 \cdot 1 \mu \mathrm{g} / \mathrm{ml}$ was used. S12 was detected using biotinylated horse antimouse lgG (diluted 1 in 250; Vector, Burlingame, California, USA), followed by Streptavidin-horseradish peroxidase (HRP) (diluted 1 in 500; Dako, Glostrup, Denmark) and visualised by diaminobenzidine (DAB; Sigma, St Louis, Missouri, USA) or amine-ethylcarbazole (AEC; Sigma) with $0.02 \% \mathrm{H}_{2} \mathrm{O}_{2}$ in phosphate buffered saline (PBS) (pH 7.4). Alternatively, S12 was detected using goat antimouse lgG2a and HRP (diluted 1 in 100; Southern Biotechnology Ass.,
Birmingham, UK) and directly visualised using DAB or AEC with $0.02 \% \mathrm{H}_{2} \mathrm{O}_{2}$.

CS1-4 is a mixture of four different monoclonal antibodies of the $\operatorname{lgGl}$ subclass and was obtained from Dako. Final concentrations used for immunohistochemistry ranged from 0.3 to $0.6 \mu \mathrm{g} / \mathrm{ml}$. Detection was performed by either biotinylated goat antimouse lgG as described above or by goat antimouse $\lg \mathrm{G} 1$ / alkaline phosphatase (diluted 1 in 20; Southern Biotechnology Ass.) and visualised using naphthol AS-MX phosphate/fast blue BB/0.2 M Tris- $\mathrm{HCl}$ (pH 8.5) (Sigma). Endogenous alkaline phosphatase activity was blocked by adding $1 \mathrm{mM}$ levamisol (Sigma) to the reaction mixture.

\section{TISSUE SECTIONS}

Cryostat sections $(4 \mu \mathrm{m})$ were mounted on poly-L-lysine coated (PLL; Sigma) slides and air-dried for at least one hour at room temperature. After drying, the sections were alternatively fixed for 10 minutes with $4 \%$ freshly made parafromaldehyde/PBS, 4\% buffered formaldehyde, methanol (absolute), and acetone (absolute).

Formalin fixed, paraffin wax embedded tissue sections $(5 \mu \mathrm{m})$ were mounted on PLL coated slides and routinely deparaffinised.

\section{DOUBLE STAINING PROCEDURES FOR THE} SIMULTANEOUS DETECTION OF S12 AND CS1-4 AND BLOCKING EXPERIMENTS

For the simultaneous detection of $\mathrm{S} 12$ and CS1-4 antigens on tissue sections, five cases of EBV positive Hodgkin's disease were used. Formalin fixed, paraffin wax embedded tissue sections $(5 \mu \mathrm{m})$ were routinely deparaffinised and incubated with $\mathrm{S} 12$ and $\mathrm{CS} 1-4$ for one hour. The $\operatorname{lgG} 1$ and $\lg G 2 a$ antibodies were detected by simultaneous incubation with goat antimouse $\operatorname{lgG} 1$ labelled with alkaline phosphatase (diluted 1 in 20) and goat antimouse lgG2a labelled with HRP (diluted 1 in 100). Thereafter, alkaline phosphatase was first visualised as described above, followed by the visualisation of HRP using AEC. To investigate whether S12 or CS1-4 could block all epitopes of the other anti-LMP-1 monoclonal antibody, tissue sections were pre-incubated with a tenfold excess of one monoclonal antibody whereafter the tissue sections were incubated with the other anti-LMP-1 monoclonal antibody.

Combination of immunohistochemical detection of LMP-1 and RNA in situ hybridisation using EBER-1 and -2 specific probes has been described extensively elsewhere. ${ }^{4}$

\section{Results}

REACTION PATTERN OF S12 AND CS1-4 IN NORMAL TISSUE

The cross-reactivity of $\mathrm{S} 12$ and $\mathrm{CS} 1-4$ is summarised in the table. $\mathrm{S} 12$ showed reactivity with different cells in normal skin. Several cells in the basal layer showed cytoplasmic staining. Although the precise nature of these cells is 
Reaction pattern of S12 and CS1-4 in normal tissue

\begin{tabular}{|c|c|c|c|}
\hline Tissue & $S 12$ & $C S 1-4$ & Reactivity \\
\hline $\begin{array}{l}\text { Large intestine } \\
\text { Appendix } \\
\text { Pancreas } \\
\text { Brain }\end{array}$ & $\begin{array}{l}\text { Positive (P) } \\
\text { Positive (P) } \\
\text { Positive (P,F) } \\
\text { Positive (P) }\end{array}$ & $\begin{array}{l}\text { Negative } \\
\text { Negative } \\
\text { Negative } \\
\text { Weak (P) }\end{array}$ & $\begin{array}{l}\text { Sporadic epithelial cells } \\
\text { Sporadic epithelial cells } \\
\text { Islets of Langerhans } \\
\text { Cytoplasmic staining in layers three and } \\
\text { four of the cortex }\end{array}$ \\
\hline $\begin{array}{l}\text { Peripheral nerve } \\
\text { Skin }\end{array}$ & $\begin{array}{l}\text { Positive }(\mathrm{P}, \mathrm{F}) \\
\text { Positive }(\mathrm{P})\end{array}$ & $\begin{array}{l}\text { Weak }(\mathrm{P}, \mathrm{F}) \\
\text { Weak }(\mathrm{P})\end{array}$ & $\begin{array}{l}\text { Myelin-like staining } \\
\text { Resembling dentritic melanotic cells (both } \\
\text { antibodies). Myoepithelial cells surrounding } \\
\text { hair follicles and other adnexa (CS1-4 only) }\end{array}$ \\
\hline
\end{tabular}

$\mathrm{P}=$ paraffin wax embedded tissue sections; $\mathrm{F}=$ frozen tissue sections.

All other tissues tested, as listed in the Methods section, did not react with S12 or CS1-4; no cross-reactivity was observed in EBV negative non-malignant lymph nodes.

not clear, their morphology resembles that of dendritic melanocytes rather than Langerhans' cells, as the positive cells were exclusively found in the basal cell layer of the epidermis. In brain tissue synaptophysin-like staining was observed in layers three and four of the cortex. Peripheral ganglion cells and peripheral nerves showed myelin-like staining. Moreover, pancreatic islets showed cytoplasmic staining (fig 1). The pancreatic islets showed strong reactivity when formalin fixed, paraffin wax embedded material was used. Frozen tissue sections fixed with (para)formaldehyde also showed similar reactivity. No staining of the pancreatic islets was observed when the frozen tissue sections were fixed in acetone or methanol. Otherwise, results were independent of fixation.

CS1-4 also reacted with the basal cells in the epidermis of normal skin, but cross-reactivity in normal brain and peripheral nerve tissue was also observed. Staining with S12 was always much stronger. Moreover, in contrast to S12, myoepithelial cells and smooth muscle cells also showed faint cross-reactivity; no crossreactivity with pancreatic islets was observed.

DETECTION OF LMP-1 IN EBV ASSOCIATED LYMPHOPROLIFERATIVE DISEASES

In EBV positive Hodgkin's disease both monoclonal antibodies stained H-RS cells (fig 2). Both formalin fixed, paraffin wax embedded and frozen tissue sections could be used. Besides the typical H-RS cells, S12 also stained a large number of "intermediate sized" cells (resembling an atypical blastoid morphology) and also a considerable number of small, morphologically non-malignant lymphoid cells. These smaller cells were only observed sporadically when CS1-4 was used. Double staining with S12 (lgG2a) and CS1-4 (lgG1) revealed that large atypical cells frequently showed "true" double staining (3A). Smaller cells reacted exclusively with S12 (figs $3 \mathrm{~B}$ and $3 \mathrm{C}$ ), whereas S12 negative/CS1-4 positive intermediate sized and small cells were never observed. Using EBER-1 and -2 probes in combination with $\mathrm{S} 12$ and $\mathrm{CS} 1-4$, the H-RS cells frequently showed staining for both the EBER-1 and -2 RNA and LMP-1 protein. This co-expression was also observed in a substantial number of the smaller EBER-1 and -2 positive cells (fig 4), but only when S12 was used. In all cases of EBV positive Hodgkin's disease a considerable number of EBER-1 and -2 positive large, intermediate and small cells could be visualised without any LMP-1 being detected. These EBER positive/LMP-1 negative cells were present more frequently in tissue sections stained with CS1-4 than with S12.

In infectious mononucleosis and in the different EBV positive B and T non-Hodgkin's lymphoma cell sections the staining pattern was different. In all of these cases most of the EBER-1 and -2 positive cells were LMP-1 negative (fig 5). Frozen tissue sections fixed with $4 \%$ (para)formaldehyde, methanol or acetone showed much more positive cells compared with formalin fixed, paraffin wax embedded material. Again, S12 positive cells outnumbered the CS1-4 positive cells.

Finally, blocking experiments were performed to investigate whether S12 and CS1-4 recognise different epitopes. Pre-incubation with a tenfold excess of CS1-4 was unable to prevent specific binding of $\mathrm{S} 12$ and vice versa, indicating that, at least in part, different epitopes of the LMP-1 molecule were detected.

\section{Discussion}

The results of this study show that $\mathrm{S} 12$ has certain advantages over CS1-4 when EBV associated lymphoproliferative disorders were investigated for the expression of LMP-1; in EBV associated B and T cell non-Hodgkin's lymphoma more cells were stained and the signals were moderately stronger. The number of EBER-1/2 positive neoplastic cells outnumbered the LMP-1 positive cells in all cases. This indicates that despite the clonal character of these tumours, there is variability in EBV gene expression, particularly of LMP-1. This was also true for infectious mononucleosis where only some of the EBER-1 and -2 positive cells expressed detectable LMP-1. Although in Hodgkin's disease both S12 and CS1-4 could be used on formalin fixed, paraffin wax embedded material or frozen tissue sections, S12 stained more $\mathrm{H}-\mathrm{RS}$ cells and also more smaller EBER-1 and -2 positive cells as observed using double staining techniques for EBER-1 and -2 messenger RNAs and immunohistochemistry for LMP-1 detection.

In previous studies CS3 and CS4 crossreacted in immunoblots with certain cellular proteins of a molecular weight of $41 \mathrm{kDa}$ and $44 \mathrm{kDa} .{ }^{14}$ Although cross-reactivity was never observed on EBV negative/control lymphoid tissue, $\mathrm{S} 12$ has a slightly different reactivity pattern on normal human tissues than CS1-4. These differences are remarkable as both sets of monoclonal antibodies are directed against the same $46 \mathrm{kDa}$ fusion protein. ${ }^{14}{ }^{15} \mathrm{Our}$ data on double staining using both anti-LMP-1 antibodies and the observation that pre-incubation with S12 or CS1-4 could not prevent specific binding of the other anti-LMP-1 antibody confirm that different epitopes are detected. Similar results were observed in immunoblots: pre-incubation with CS1-4 was unable to prevent specific binding of $\mathrm{S} 12$ and vice versa (data not shown). The fact that the staining pattern of $S 12$ in EBV infected cells was slightly different from that of CS1-4 suggests that the epitope of $\mathrm{S} 12$ is differentially 

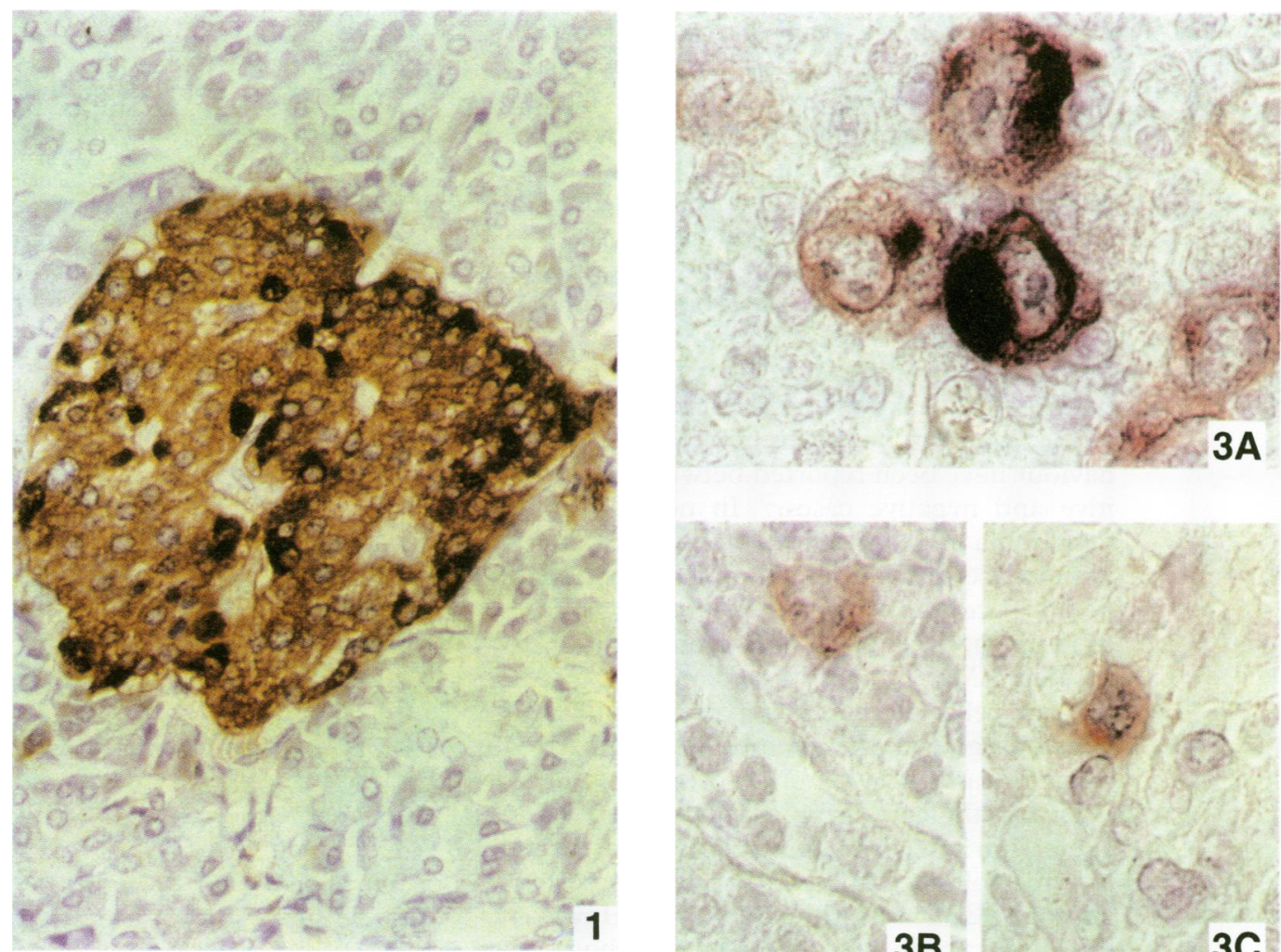

Figure 1 Formalin fixed, paraffin wax embedded tissue sections of normal pancreas stained with S12. Note the non-specific staining of the pancreatic islets by S12. Visualisation using $\mathrm{DAB} / \mathrm{H}_{2} \mathrm{O}_{2}$ (brown); original magnification $\times 300$.

Figure $2 \mathrm{~A}$ : Lymph node with Hodgkin's disease. Large atypical cells reacted with $\mathrm{S} 12$. Visualisation using $\mathrm{AEC} / \mathrm{H}_{2} \mathrm{O}_{2}$ (red); original magnification $\times 520$. B: The same lymph node stained with CS1-4. Visualisation using alkaline phosphatase (blue); original magnification $\times 520$.

Figure 3 A: Double staining with $S 12$ and CS1-4. S12 (gG2a) was detected using a subclass specific antibody and was visualised with $A E C / H_{2} O_{2}$. Staining with CS1-4 (gG1) was visualised using alkaline phosphatase (blue). Note that besides the double staining (mixture of red and blue), some red staining is also visible. $B$ and C: Same section as fig $2 A$. Besides the large atypical cells showing double staining, some small, morphologically "nonmalignant" cells were also stained, but only with $S 12$ (red). No staining with CS1-4 was detected in these smaller cells. Original magnification $\times 825$. Figure 4 Combination between RNA in situ hybridisation using EBER-1 and -2 RNA probes (visualisation using $D A B /-\mathrm{Ni}_{2} / \mathrm{H}_{2} \mathrm{O}_{2}$ with silver enchancement; black grains) and $L M P-1$ detected by $\mathrm{S} 12\left(\mathrm{DAB} / \mathrm{H}_{2} \mathrm{O}_{2}\right.$ brown). Note that not only are the large atypical cells stained with both, but also the morphologically "non-malignant" lymphoid cells (arrowhead). Original magnification $\times 825$.

Figure 5 Immunoblastic $B$ cell non-Hodgkin's lymphoma in a bone marrow transplant recipient stained with $\mathrm{S}_{12}$. Visualisation using $A E C / \mathrm{H}_{2} \mathrm{O}_{2}$ (red); original magnification $\times 825$. 
expressed or more easily accessible than the epitopes recognised by $\mathrm{CS} 1-4$. In this regard, it is important to note that LMP-1 in its nascent form has a very short half life of two to five hours in vitro, is processed differently at the posttranslational level and sub-fragments may localise to different cellular compartments. ${ }^{1920}$

The clinical importance of LMP-1 expression in the different lymphoma groups is still obscure. It is known that EBV is more frequently present in more aggressive forms of Hodgkin's disease-for example, the mixed cellularity type ${ }^{16}$ whereas no differences in clinical behaviour have been reported between EBV positive and negative cases. ${ }^{21}$ In non-Hodgkin's lymphoma little is known about the clinical importance of EBV infection. In one study of nodal $T$ cell non-Hodgkin's lymphoma cases diffusely positive for EBER-1 and -2 also expressed LMP-1 on a limited number of the tumour cells. These cases had a significantly worse prognosis when compared with LMP-1 negative cases. ${ }^{8}$

Histopathological studies concerning LMP-1 expression in vivo might provide more insight into the role of LMP-1 in the pathogenesis of different EBV associated diseases. However, this requires optimal detection methods including immunohistochemistry. In this respect our data show that both S12 and CS1-4 detect specific, yet distinct, LMP-1 associated signals, although S12 detected more EBV positive cells and gave stronger signals than CS1-4. Therefore, we recommend $\mathrm{S} 12$ for the detection of LMP-1 in tissue sections.

We thank Dr Ph M Kluin for providing EBV positive tissue specimens from transplant recipients.

1 Henle W, Henle G. Epstein-Barr virus and infectious mononucleosis. $N$ Engl f Med 1973;288:263-4.

2 Zur Hausen H, Schulte-Holthausen H, Klein G, Henle W, Henle G, Clifford P, et al. EBV DNA in biopsies of Burkitt Henle G, Clifford P, et al. EBV DNA in biopsies of Burkitt
tumors and anaplastic carcinomas of the nasopharynx. tumors and anaplastic

3 Weiss LM, Movahed LA, Warnke RA, Sklar J. Detection of Epstein-Barr virus genomes in Reed-Sternberg cells of Hodgkin's disease. $N$ Engl $\mathcal{F}$ Med 1989;320:502-6.

4 Jiwa NM, Kanavaros P, de Bruin PC, van der Valk P, Horstman A, Vos W, et al. Presence of Epstein-Barr virus harbouring small and intermediate-sized cells in Hodgkin's disease. Is there a relationship with Reed-Sternberg cells? f Pathol 1993;170:129-36.

5 Kanavaros P, Jiwa NM, de Bruin PC, van der Valk, P, Noorduyn LA, van Heerde P, et al. High incidence of EBV genome in CD30-positive non-Hodgkin's lymphomas. $f$ Pathol 1992;168:307-15.

6 Jones JF, Shurin S, Abramowsky C, Tubbs RR, Sciotto CG, Wahl R, et al. T-cell lymphomas containing Epstein-Barr virus DNA in patients with chronic Epstein-Barr virus infections. $N$ Engl f Med 1988;318:733-41.

7 Young L, Alfieri C, Hennessy K, Evans H, O'Hara C, Anderson KC, et al. Expression of Epstein-Barr virus transformation associated genes in tissues of patients with EBV lymphoproliferative diseases. $N$ Engl $\mathscr{f}$ Med 1989; 321:1080-5.

8 De Bruin PC, Jiwa MN, van der Valk P, Van Heerde P, Ge Bruin PC, Jiwa MN, van der Valk P, Van Heerde P,
Gordijn R, Ossenkoppele GJ, et al. Detection of EpsteinBarr virus nucleic acid sequences and protein in nodal T-cell lymphomas. Relation between latent membrane protein 1 positivity and clinical course. Histopathology 1993;23:509-18.

9 Wang D, Liebowitz D, Kieff E. An EBV membrane protein expressed in immortilized lymphocytes transforms established rodent cells. Cell 1985;43:831-40.

10 Fahreus R, Rymo L, Rhim JS, Klein G. Morphological transformation of keratinocytes expressing the LMP gene of Epstein-Barr virus. Nature 1990;345:447-9.

11 Niedobitek G, Fahraeus R, Herbst H, Latza U, Ferszt A, Klein G, et al. The Epstein-Barr virus encoded membrane protein (LMP) induces phenotypic changes in epithelial protein (LMP) induces phenotypic changes in ep
cells. Virchows Archiv B Cell Pathol 1992;62:55-9.

12 Herbst H, Steinbrecher E, Niedobitek G, Young LS, Brooks $\mathrm{L}$, Muller-Lantzsch N, et al. Distribution and phenotype of Epstein-Barr virus-harbouring cells in Hodgkin's disease. Blood 1992;80:481-91.

13 Hummel M, Anagnostopoulos I, Dallenbach F, Korbjuhn P, Dimmler C, Stein H. EBV infection patterns in Hodgkin's disease and normal lymphoid tissue: expression and cellular localization of EBV gene products. Br 7 Haematol 1992; 82:689-94.

14 Rowe M, Evans HS, Young LS, Hennessy K, Kieff E, Rickinson AL. Monoclonal antibodies to the latent membrane protein of Epstein-Barr virus reveal heterogeneity of the protein and inducible expression in virus-transformed the protein and inducible expression

15 Mann KP, Staunton D, Thorley-Lawson DA. Epstein-Barr virus-encoded protein found in plasma membranes of transformed cells. $\mathcal{f}$ Virol 1985;55:710-20.

16 Pallesen G, Hamilton-Dutoit SJ, Rowe M, Young S. Expression of Epstein-Barr virus latent gene products in tumor cells of Hodgkin's disease. Lancet 1991;337:320-2.

17 Hennessy K, Fennewald S, Hummel M, Cole T, Kieff E. A membrane protein encoded by Epstein-Barr virus in latent growth transforming infection. Proc Natl Acad $S_{c i}$ USA 1984;81:7202-11.

18 Jiwa NM, van der Valk P, Mullink $\mathrm{H}$, Vos W, Horstman A, Maurice MM, et al. Epstein-Barr virus DNA in ReedSternberg cells of Hodgkin's disease is frequently asSternberg cells of Hodgkin's disease is frequently as-
sociated with CR2 (EBV receptor) expression. Hissociated with CR2 (EBV
topathology 1992;21:51-7.

19 Moorthy RK, Thorley-Lawson DA. Biochemical, genetic and functional analyses of the phosphorylation site on the Epstein-Barr virus encoded oncogenic latent membrane protein LMP-1. F Virol 1993;67:2637-45.

20 Liebowitz D, Kopan R, 'Fuchs E, Sample J, Kieff E. An EBV transforming protein associated with vimentin in lymphocytes. Mol Cell Biol 1987;7:2299-308.

21 Fellbaum C, Hansmann ML, Niedermeyer H, Kraus I, Alavaikko MJ, Blanco G, et al. Influence of Epstein-Barr virus genomes on patient survival in Hodgkin's disease. Hematopathology 1992;98:319-23. 